\title{
Erratum: Simulating flow in karst aquifers at laboratory and sub-regional scales using MODFLOW-CFP
}

\author{
Josue Jacob Gallegos • Bill X. Hu • Hal Davis
}

\section{Erratum to: Hydrogeology Journal (2013) DOI 10.1007/s10040-013-1046-4}

Figure $3 \mathrm{~b}$ in the original article omitted the simulated layer of the CFPM1 model, which held the CFP conduit nodes. The new Figure $3 \mathrm{~b}$ contains the bottom layer and shows the CFPM1 simulated heads for the bottom layer.

An early version of the Wakulla Springs simulated discharge graph was inadvertently used as Figure 9 in the original article, showing peak discharge from an older simulation run of the CFPM1 model. The new Figure 9 shows the correct peak discharge of the final CFPM1 model of Wakulla Springs.

In the section 'Sub-regional scale study', subsection 'Numerical model', the first two sentences should read: "The sub-regional CFPM1 model consists of 288 rows and 258 columns. Model cells are $500 \mathrm{ft} \times 500 \mathrm{ft}(152.4 \mathrm{~m}$ $\times 152.4 \mathrm{~m}$ ) horizontally."

Published online: 13 November 2013

(C) Springer-Verlag Berlin Heidelberg 2013

The online version of the original article can be found at http:/ dx.doi.org/10.1007/s10040-013-1046-4.

\section{J. J. Gallegos • B. X. Hu (『)}

Geology Program, Department of Earth,

Ocean and Atmospheric Sciences,

Florida State University, Tallahassee, FL 32306, USA

e-mail: bill.x.hu@gmail.com

H. Davis

2625 Vergie Court, Tallahassee, FL 32303, USA
In the section 'Sub-regional scale study', subsection 'Transient model', the following text was not deleted during the editing process and now needs to be removed from the text: "These results could be explained in that the CFP model overestimates the water exchange between the conduit and the matrix, while the MODFLOW model underestimates the exchange. During the discharge peak period, hydraulic pressure in conduit is higher than that in matrix, so the water can move from conduit into matrix. On the other hand, during the discharge tailing period, the hydraulic head in the matrix is higher than that in the conduit, so the water will move from matrix to conduit. The CFP model overestimates the water movement in the both periods, but the MODFLOW under-estimates it at later time."

In the section 'Sub-regional scale study', at the end of subsection 'Transient model', the third-from-last sentence should read: "For Spring Creek Springs, the error percentage of the total discharge simulated by the CFPM1 model was $21.6 \%$." (not $30.6 \%$ ). 

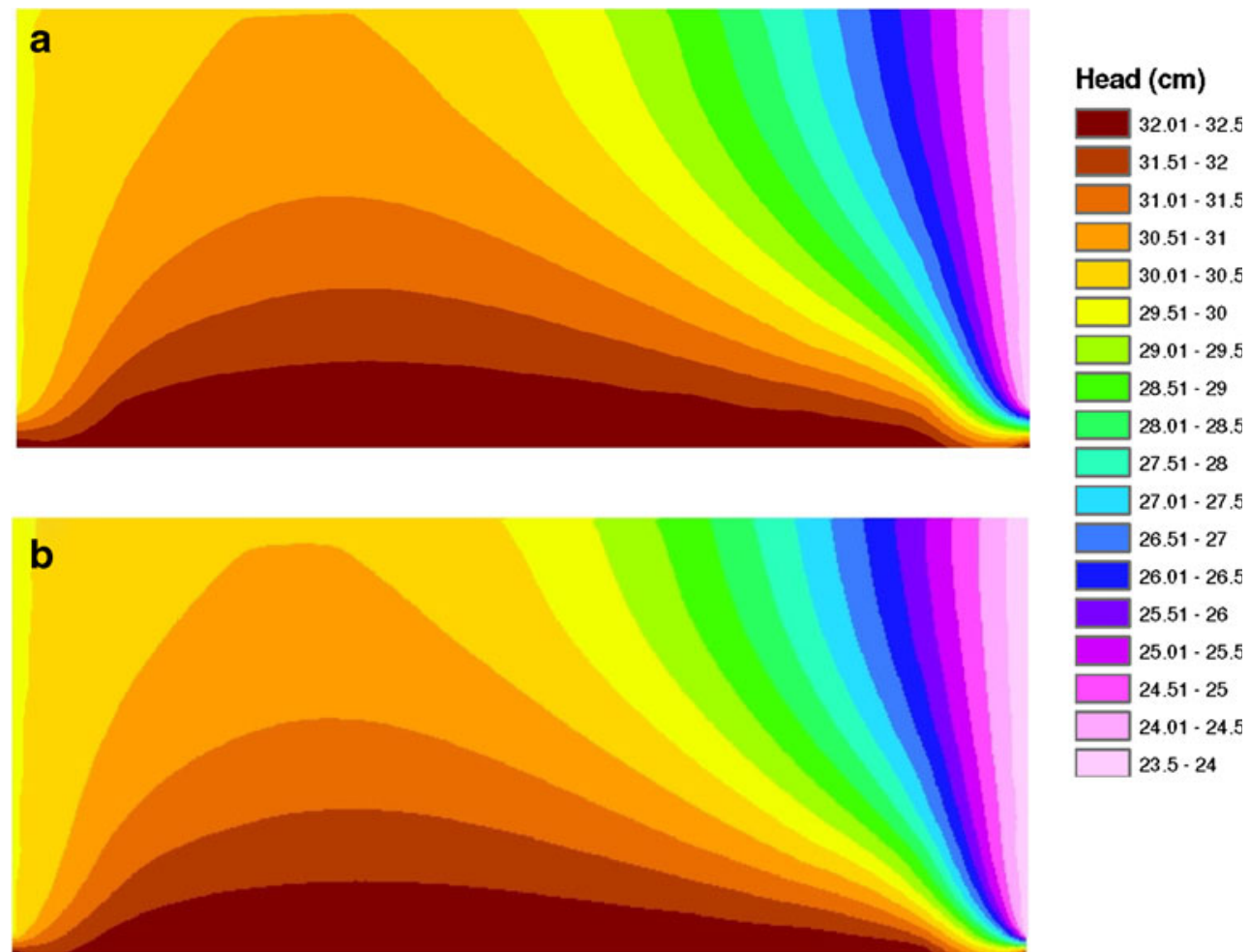

Fig. 3 Contour lines of simulated head with contour interval of $0.5 \mathrm{~cm}$. a Simulated head from the MODFLOW-2005 model. b Simulated head from the CFPM1 model

Wakulla Springs Simulated Discharge

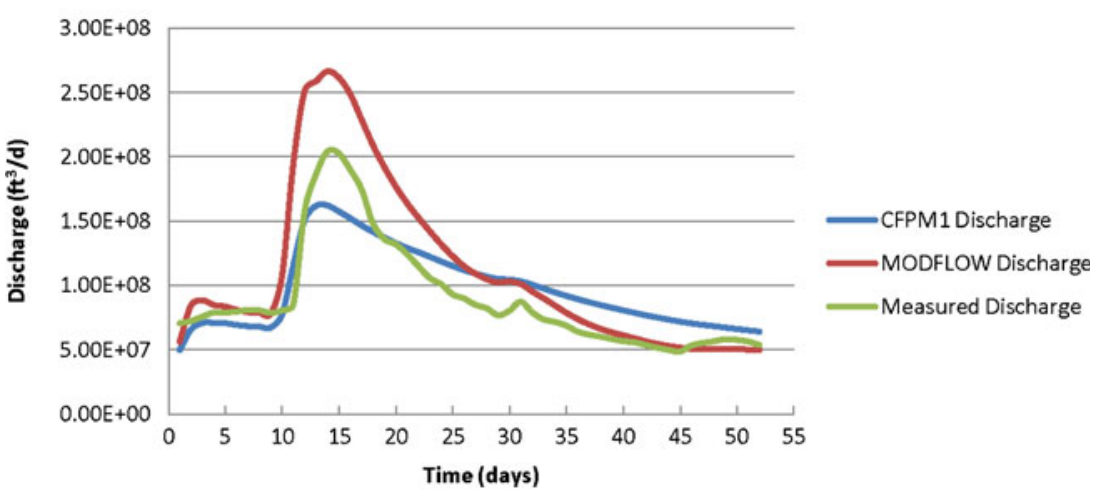

Spring Creek Group Simulated Discharge

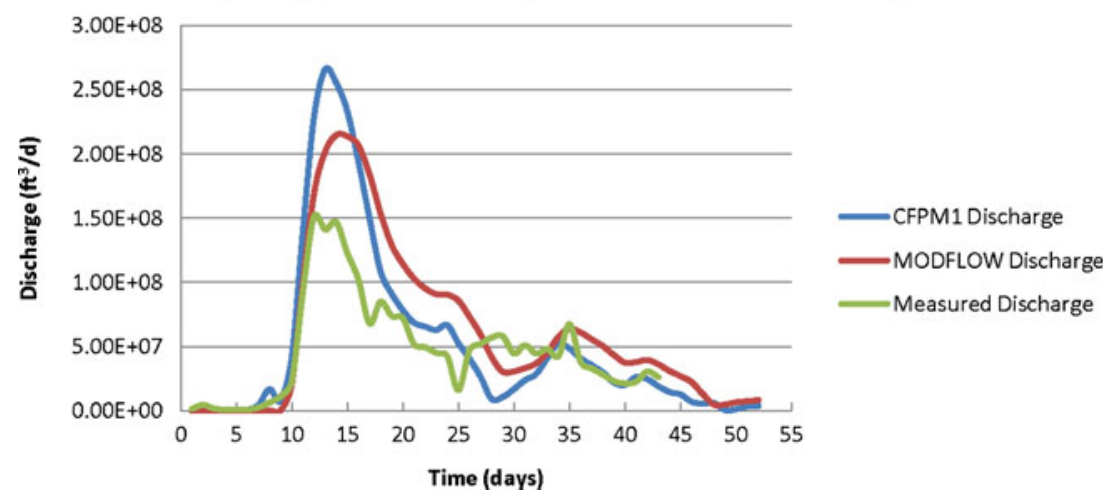

Fig. 9 Simulation results of the Transient Storm run with discharge at Wakulla Springs and Spring Creek Springs Group. Both the CFPM1 model and the MODFLOW model have the same hydraulic conductivity values except within model cells where conduits are simulated 